\title{
PENGARUH PENGGUNAAN MEDIA KARTU PENJUMLAHAN DAN PENGURANGAN BILANGAN BULAT PADA HASIL BELAJAR MATEMATIKA SISWA KELAS VII SMPN 3 LAGE
}

Oleh : Sertin Allolayuk, S.Si., M.Pd.

Email : sertin_allolayuk@yahoo.co.id

\begin{abstract}
ABSTRAK
Penelitian ini bertujuan untuk mengkaji dan menganalisa pengaruh penggunaan media kartu penjumlahan dan pengurangan bilangan bulat pada hasil belajar matematika siswa kelas VII SMPN 3 Lage. Penelitian ini menggunakan metode eksperimen dengan pendekatan kuantitatif dan model true eksperimental design dalam bentuk pretest-posttest control design. Penelitian ini dilaksanakan di SMPN 3 Lage. Populasi dalam penelitian ini adalah seluruh siswa kelas VII SMPN 3 Lage yang berjumlah 78 siswa. Pengambilan sampel penelitian menggunakan teknik random sampel sederhana. Data dikumpulkan dengan menggunakan tes awal (pre-test) yang dianalisa dengan menggunakan uji $\mathrm{F}$ untuk melihat tingkat homogenitas sampel dan tes akhir (post-test) yang dianalisa dengan menggunakan teknik ttest polled Varian. Data yang berasal dari pre-test dan post-test dihitung dengan menggunakan program Microsoft office exel 2007 kemudian dibandingkan dengan program SPSS versi 19 for windows.

Berdasarkan hasil penelitian dan pembahasan, maka dapat disimpulkan bahwa terdapat pengaruh positif dan signifikan dalam penggunaan media kartu penjumlahan dan pengurangan bilangan bulat pada hasil belajar matematika siswa kelas VII SMPN 3 Lage. Hal ini diperoleh setelah melakukan pengujian hipotesis dengan menggunakan rumus uji t-test polled Varian $\left(\mathrm{dk}=\mathrm{n}_{1}+\mathrm{n}_{2}-2=24+25-2=47\right)$ berdasarkan taraf kepercayaan $95 \%$ uji pihak kanan diperoleh $t_{\text {hitung }}>$ $\mathrm{t}_{\text {tabel }}(3,521>1,678)$.
\end{abstract}

Kata Kunci: Media Pembelajaran, Media kartu penjumlahan dan pengurangan bilangan bulat, hasil belajar.

\section{PENDAHULUAN}

Belajar matematika dapat membuat siswa menjadi manusia yang berpikir secara logis, kritis, dan kreatif. Pada kenyataannya mata pelajaran matematika dianggap sulit oleh sebagian besar siswa diberbagai sekolah, salah satunya dikelas VII SMPN 3 Lage. Masih banyak siswa yang mengalami kesulitan belajar matematika. Beberapa faktor yang di 
menjadi penyebab permasalahan tersebut, antara lain siswa menganggap bahwa materi yang diajarkan sulit karena kemampuan akal siswa yang masih terbatas, siswa malu atau segan bertanya kepada guru, siswa kurang aktif dan cenderung bosan saat belajar karena dalam proses pembelajaran penyampaian materi lebih banyak ceramah dan bersifat monoton. Selain itu, kurangnya media pembelajaran yang menunjang juga mempengaruhi hasil belajar siswa.

Berdasarkan permasalahan pada sekolah tersebut maka salah satu cara yang dapat dilakukan guru untuk meningkatkan kualitas pembelajaran matematika yaitu dengan menggunakan media pembelajaran. Salah satu media pembelajaran yang dapat digunakan untuk membantu siswa dalam memahami operasi hitung penjumlahan dan pengurangan bilangan bulat adalah dengan menggunakan media kartu penjumlahan dan pengurangan bilangan bulat. Berdasarkan uraian di atas maka peneliti melakukan penelitian tentang "Pengaruh Penggunaan Media Kartu penjumlahan dan pengurangan Bilangan Bulat Pada Hasil Belajar Matematika Siswa Kelas VII SMPN 3 Lage”.

Berdasarkan latar belakang yang telah diuraikan, maka rumusan masalah dalam penelitian ini adalah "apakah terdapat pengaruh positif dan signifikan penggunaan media kartu penjumlahan dan pengurangan bilangan bulat pada hasil belajar matematika siswa kelas VII SMPN 3 Lage?”. Berdasarkan rumusan masalah di atas, tujuan penelitian ini adalah untuk mengkaji dan menganalisis pengaruh penggunaan media kartu penjumlahan dan pengurangan bilangan bulat terhadap hasil belajar matematika siswa kelas VII SMPN 3 Lage. Hasil penelitian ini diharapkan dapat memperkaya teori dalam pengembangan ilmu pendidikan matematika khususnya yang berkaitan dengan penggunaan media kartu penjumlahan dan pengurangan bilangan bulat.

\section{TEORI}

Menurut Hilgard (Suryabrata, 2002) bahwa "belajar merupakan proses perbuatan yang dilakukan secara sadar yang kemudian menimbulkan perubahan, yang keadaannya berbeda dari perbuatan yang sebelumnya". Belajar di sekolah mempunyai peranan yang sangat penting, khususnya belajar matematika. Berdasarkan beberapa pendapat di atas, dapat disimpulkan bahwa belajar adalah suatu proses usaha yang dilakukan untuk memperoleh suatu perubahan tingkah laku yang baru secara keseluruhan sebagai hasil pengalamannya sendiri dalam interaksi dengan lingkungan. Sedangkan belajar matematika adalah proses dalam diri siswa yang hasilnya berupa perubahan pengetahuan, sikap, keterampilan dan untuk menerapkan konsep-konsep, struktur dan pola dalam matematika, sehingga menjadikan siswa berpikir logis, kreatif, sistematis dalam kehidupan sehari-hari.

Hasil belajar adalah suatu penilaian akhir dari proses dan pengenalan yang telah dilakukan berulang-ulang, serta akan tersimpan dalam jangka waktu yang lama atau bahkan tidak akan hilang karena hasil belajar turut serta dalam membentuk pribadi individu yangselalu ingin mencapai hasil yang lebih baik lagi sehingga akan merubah cara berpikir serta menghasilkan perilaku kerja yang lebih baik. 
Media pembelajaran merupakan segala sesuatu yang digunakan dalam kegiatan pembelajaran agar dapat merangsang pikiran, perasaan, minat dan perhatian siswa sehingga proses interaksi antara guru dan siswa dapat berlangsung secara tepat dan berdaya guna. Media pembelajaran dapat memberikan pengalaman belajar kepada siswa, karena siswa mengalami sendiri prosesnya.

Media kartu adalah salah satu alat peraga matematika yang membahas mengenai operasi penjumlahan dan pengurangan pada bilangan bulat. Media kartu ini terdiri dari kartu positif dan kartu negatif. (Suharjana, 2009). Kartu ini dapat terbuat dari kertas tebal yang bentuknya boleh persegi, persegi panjang, segitiga atau lingkaran. Hal terpenting dalam pembentukannya adalah adanya tanda positif dan negatif.

Adapun beberapa ketentuan yang harus disepakati dalam memperagakan kartu penjumlahan dan pengurangan bilangan bulat (Suharjana, 2009) sebagai berikut:

- Menyediakan kartu bertanda “+” dan bertanda “_“ minimal masing-masing 20 kartu. Kartu ini digunakan untuk mewakili bilangan bulat bertanda positif (+) dan bilangan bulat bertanda (-).

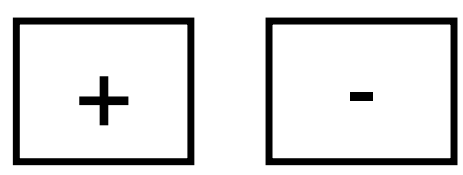

- Operasi penjumlahan adalah proses menambah/memberi kartu "+” atau kartu "_“, sedangkan operasi pengurangan adalah proses mengambil kartu “+” atau “_“

Dengan kata kuncinya adalah:

Ditambah $=$ diberi

Dikurangi $=$ diambil

Hasil $=$ sisa/kartu yang tidak berpasangan

- Apabila kartu bertanda positif bertemu (berpasangan) dengan kartu bertanda negatif maka menghasilkan 0 .
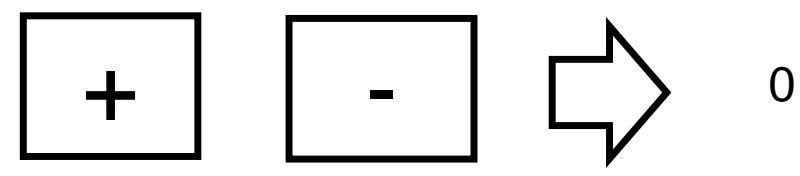

Pelaksanaan pembelajarannya yaitu setelah guru memberi petunjuk mengenai penggunaan media kartu tersebut, guru membagi kelompok-kelompok belajar, kemudian siswa bekerja sama mempelajarinya dan mengerjakan soal-soal latihan yang diberikan oleh guru. Setelah siswa memahami dan mengusai konsep penjumlahan dan pengurangan bilangan bulat, maka kegiatan pembelajaran dilakukan secara mandiri. Dengan adanya media kartu tersebut diharapkan dapat memotivasi siswa dalam kegiatan pembelajaran yang aktif dan mampu membantu siswa untuk mendalami pemahaman mengenai operasi penjumlahan dan pengurangan bilangan bulat, sehingga hasil belajar yang dicapai bisa 
lebih baik lagi. Tinjauan materi dalam penelitian ini adalah mengenai penjumlahan dan pengurangan bilangan bulat (Kemdikbud, 2013).

\section{METODE PENELITIAN}

Penelitian ini menggunakan metode eksperimen yang terbagi menjadi dua kelompok yaitu kelompok eksperimen (kelompok uji coba) dan kelompok kontrol (kelompok pembanding). Pada penelitian ini digunakan model true experimental design dalam bentuk pretest-posttestcontrol group Design (Sugiyono, 2012). Desain penelitian ini dapat digambarkan sebagai berikut:

\begin{tabular}{|cccc|}
\hline $\mathbf{R}$ & $\mathbf{0}_{1}$ & $\mathrm{X}$ & $\mathbf{0}_{2}$ \\
$\mathrm{R}$ & $\mathbf{0}_{3}$ & & $\mathbf{0}_{4}$ \\
\hline
\end{tabular}

Keterangan:

$\mathrm{R}=$ Kelompok eksperimen dan kontrol diambil secara random

$\mathrm{O}_{1} \& \mathrm{O}_{3}=$ Kedua kelompok tersebut diobservasi dengan menggunakan pretest untuk mengetahui kemampuan awal yang diharapkan kemampuan awalnya sama.

$\mathrm{O}_{2}=$ Hasil belajar dengan menggunakan media kartu penjumlahan dan pengurangan bilangan bulat

$\mathrm{O}_{4}=$ Hasil belajar yang tidak menggunakan media kartu penjumlahan dan pengurangan bilangan bulat

$\mathrm{X}=$ treatment . Kelompok eksperimen sebagai kelompok yang diberikan treatment, yakni dengan penggunaan media kartu penjumlahan dan pengurangan bilangan bulat. Sedangkan kelompok kontrol tidak diberi treatment

Penelitian ini dilaksanakan di kelas VII SMPN 3 Lage, kecamatan Lage, Kabupaten Poso, Provinsi Sulawesi Tengah. Populasi dalam penelitian ini adalah seluruh siswa kelas VII SMPN 3 Lage pada tahun pelajaran 2015/2016. Sampel adalah bagian dari jumlah dan karakteristik yang dimiliki oleh populasi (Sugiyono, 2012). Sampel dalam penelitian ini terdiri dari dua kelompok yang ditetapkan secara random dengan menggunakan model undian. Instrumen yang digunakan dalam penelitian ini adalah tes dalam bentuk essay test (tes uraian). Data pretest yang telah diperoleh melalui tes awal dianalisis dengan menggunakan rumus uji F yang dikemukakan oleh Sugiyono (2012) untuk melihat homogenitas sampel.

$$
\mathrm{F}_{\text {hitung }}=\frac{\text { Variansi terbesar }}{\text { Variansi terkecil }}
$$

Selanjutnya $\mathrm{F}_{\text {hitung }}$ dibandingkan pada $\mathrm{F}_{\text {tabel }}$, dengan $\mathrm{dk}$ pembilang $\mathrm{n}-1$ dan $\mathrm{dk}$ penyebut $\mathrm{n}-1$ serta taraf kepercayaan $95 \%(\alpha=0.05)$. 
Kriteria keputusan:

Jika $F_{\text {hitung }} \leq \mathrm{F}_{\text {tabel }}$, data homogen

Jika $\mathrm{F}_{\text {hitung }}>\mathrm{F}_{\text {tabel }}$, data tidak homogen

Uji F dilakukan dengan menggunakan variansi data, sehingga rumus variansi yang digunakan sebagai berikut:

$$
\operatorname{Variansi}\left(\mathrm{s}^{2}\right)=\frac{\sum(\mathrm{x}-\overline{\mathrm{x}})^{2}}{\mathrm{n}-1}
$$

Selanjutnya data yang diperoleh melalui post-test dianalisa dengan menggunakan rumus $t$-test polled Varian (Sugiyono, 2012) sebagai berikut:

$$
\mathrm{t}=\frac{\overline{\mathrm{X}}_{1}-\overline{\mathrm{X}}_{2}}{\sqrt{\frac{\left(\mathrm{n}_{1}-1\right) \mathrm{S}_{1}{ }^{2}+\left(\mathrm{n}_{2}-1\right) \mathrm{S}_{2}{ }^{2}}{\mathrm{n}_{1}+\mathrm{n}_{2}-2}\left(\frac{1}{\mathrm{n}_{1}}+\frac{1}{\mathrm{n}_{2}}\right)}}
$$

dengan $\mathrm{dk}=\mathrm{n}_{1}+\mathrm{n}_{2}-2$

keterangan: $\quad \overline{\mathrm{X}}_{1} \quad=$ rata-rata hasil belajar kelompok eksperimen

$\overline{\mathrm{X}}_{2} \quad=$ rata-rata hasil belajar kelompok kontrol

$\mathrm{S}_{1}{ }^{2}=$ variansi sampel 1

$\mathrm{S}_{2}{ }^{2}=$ variansi sampel 2

$\mathrm{n}_{1} \quad=$ banyak subjek kelompok eksperimen

$\mathrm{n}_{2}=$ banyak subjek kelompok kontrol

Sebelum menggunakan rumus tersebut, terlebih dahulu mencari rata-rata, variansi, nilai dari kelompok eksperimen dan kelompok kontrol dengan menggunakan rumus yang dikemukakan oleh Sugiyono (2012) yaitu:

$$
\begin{array}{lll}
\text { Rata-rata } & =\quad \overline{\mathrm{X}}=\frac{\sum \mathrm{X}}{\mathrm{n}} \\
\text { Variansi } & = & s^{2}=\frac{\sum(\mathrm{x}-\overline{\mathrm{x}})^{2}}{\mathrm{n}-1}
\end{array}
$$

Setelah $t_{\text {hitung }}$ diperoleh, selanjutnya dibandingkan dengan $t_{\text {tabel }},\left(d k=n_{1}+n_{2}-2\right)$ berdasarkan taraf kepercayaan 95\% $(\alpha=0.05)$ uji pihak kanan. Berdasarkan pengujian hipotesis penelitian, untuk menganalisis data hasil penelitian tersebut menggunakan bantuan program Microsoft Excel 2007 dengan pembanding program SPSS versi 19 for windows (Yus, 2011). 


\section{HASIL PENELITIAN}

Data penelitian ini diambil dari dua kelompok yaitu kelompok eksperimen dengan dan kelompok kontrol. Dari hasil pre-test peneliti menggunakan uji homogenitas varian untuk mendapatkan apakah kedua kelompok tersebut homogen.

Tabel 1 Ringkasan Data Pre-test dan Post-test Kelompok Eksperimen dan Kelompok Kontrol

\begin{tabular}{|l|l|l|l|l|}
\hline \multirow{2}{*}{ Keterangan } & \multicolumn{2}{|l|}{ Data Pre-test } & \multicolumn{2}{l|}{ Data Post-test } \\
\cline { 2 - 5 } & $\begin{array}{l}\text { Kelompok } \\
\text { Eksperimen }\end{array}$ & $\begin{array}{l}\text { Kelompok } \\
\text { Kontrol }\end{array}$ & $\begin{array}{l}\text { Kelompok } \\
\text { Eksperimen }\end{array}$ & $\begin{array}{l}\text { Kelompok } \\
\text { Kontrol }\end{array}$ \\
\hline Jumlah siswa & 24 & 25 & 24 & 25 \\
\hline Nilai Minimum & 26 & 26 & 28 & 23 \\
\hline Nilai Maksimum & 38 & 37 & 45 & 40 \\
\hline Jumlah nilai & 744 & 774 & 892 & 800 \\
\hline Rata-rata & 31 & 30,96 & 37,167 & 32 \\
\hline
\end{tabular}

Taraf signifikan $(\alpha)=0.05$

\section{Kelompok Eksperimen}

$\mathrm{S}_{1}^{2}=\frac{\sum\left(x_{1}-\overline{X_{1}}\right)^{2}}{\mathrm{n}-1}$

$\mathrm{S}_{1}{ }^{2}=10,435$ (varian terkecil

\section{Kelompok Kontrol}

$\mathrm{S}_{2}^{2}=\frac{\sum\left(x_{2}-\overline{X_{2}}\right)^{2}}{\mathrm{n}-1}$

$\mathrm{S}_{2}{ }^{2}=12,040$ (varian terbesar)

Sehingga diperoleh:

$\mathrm{F}_{\text {hitung }}=\frac{\text { variansi terbesar }}{\text { variansi terkecil }}, \mathrm{F}_{\text {hitung }}=\frac{12,040}{10,435} \rightarrow \mathrm{F}_{\text {hitung }}=1,154$

Selanjutnya $F_{\text {hitung }}$ dibandingkan dengan $F_{\text {tabel }}$ dengan dk pembilang $=25-1=24$ dan $\mathrm{dk}$ penyebut $=24-1=23$. Berdasarkan $\mathrm{dk}$ tersebut dan taraf kepercayaan $95 \%$ $(\alpha=0.05)$ maka diperoleh nilai $\mathrm{F}_{\text {tabel }}=2,005$. Sehingga, terlihat bahwa $1,154<2,005$ atau $F_{\text {hitung }}<\mathrm{F}_{\text {tabel }}$. Dari hasil tersebut, dapat disimpulkan bahwa kedua data tersebut homogen.

Hipotesis penelitian di atas menggunakan rumus t-test polled Varian. Untuk memudahkan menghitung rata-rata dan nilai varian kelompok eksperimen dan kelompok kontrol dari rumus tersebut adalah sebagai berikut: 
Rata-rata kelompok eksperimen

$$
\begin{aligned}
\overline{X_{1}} & =\frac{\sum \overline{X_{1}}}{\mathrm{n}} \\
& =37,167
\end{aligned}
$$

\section{Varian kelompok eksperimen}

$$
\begin{aligned}
\mathrm{S}_{1}^{2} & =\frac{\sum\left(x_{1}-\overline{X_{1}}\right)^{2}}{\mathrm{n}-1} \\
& =27,083
\end{aligned}
$$

\section{Rata-rata kelompok kontrol}

$$
\begin{aligned}
\overline{X_{2}} & =\frac{\sum \overline{X_{2}}}{\mathrm{n}} \\
& =32
\end{aligned}
$$

\section{Varian kelompok kontrol}

$$
\begin{aligned}
\mathrm{S}_{2}{ }^{2} & =\frac{\sum\left(x_{2}-\overline{X_{2}}\right)^{2}}{\mathrm{n}-1} \\
& =25,623
\end{aligned}
$$

Kemudian dilanjutkan dengan menghitung $t$-test dengan menggunakan rumus $t$-test polled Varian sebagai berikut:

$$
\begin{aligned}
& t=\frac{\bar{x}_{1}-\bar{x}_{2}}{\sqrt{\frac{\left(n_{1}-1\right) S_{1}{ }^{2}+\left(n_{2}-1\right) S_{2}{ }^{2}}{n_{1}+n_{2}-2}\left(\frac{1}{n_{1}}+\frac{1}{n_{2}}\right)}} \\
& \mathbf{t}=\mathbf{3 , 5 2 1}
\end{aligned}
$$

Selanjutnya nilai $t_{\text {hitung }}$ tersebut dibandingkan dengan nilai $t_{\text {tabel }}\left(d k=n_{1}+n_{2}-2\right)$ berdasarkan taraf kepercayaan $95 \%(\alpha=0.05)$ uji pihak kanan sehingga diperoleh nilai $t_{\text {tabel }}$ sebesar 1,678. Berdasarkan kriteria pengujian hipotesis diperoleh bahwa $t_{\text {hitung }}>t_{\text {tabel }}$ $(3,521>1,678)$. Hal ini dapat digambarkan sebagai berikut:

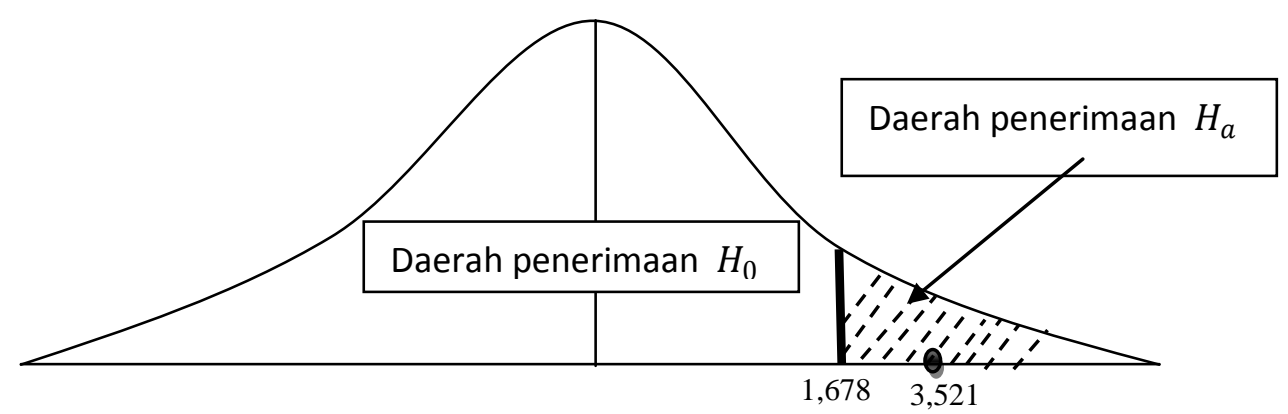

Gambar 1 Uji Hipotesis Pihak Kanan

Berdasarkan gambar 1, terlihat bahwa daerah penerimaan jatuh pada $\mathrm{Ha}$ atau dengan kata lain Ha diterima dan Ho ditolak. Karena $t_{\text {hitung }}>t_{\text {tabel }}$ sehingga dapat disimpulkan bahwa terdapat pengaruh signifikan penggunaan media kartu penjumlahan dan pengurangan bilangan bulat pada hasil belajar matematika siswa kelas VII SMPN 3 Lage. 
Selanjutnya, untuk melihat pengaruh positif maka digunakan rumus $\left(\mathrm{O}_{2}-\mathrm{O}_{1}\right)-$ $\left(\mathrm{O}_{4}-\mathrm{O}_{3}\right)=5,127$. Karena $\left(\mathrm{O}_{2}-\mathrm{O}_{1}\right)-\left(\mathrm{O}_{4}-\mathrm{O}_{3}\right)>0$ atau 5,127 >0, maka dapat disimpulkan terdapat pengaruh positif.

\section{PEMBAHASAN}

Berdasarkan analisis hasil penelitian yang diperoleh dari kedua kelompok yaitu kelompok eksperimen dan kelompok kontrol, dapat dilihat bahwa penggunaan media kartu penjumlahan dan penggurangan bilangan bulat pada kelompok eksperimen dalam proses pembelajaran dengan jumlah 892 , nilai minimum 28 , nilai maksimum 45 , nilai rata-rata 37,167 dan variansi 25,623. Sebaliknya pada kelompok kontrol yang menggunakan model pembelajaran konvensional diperoleh jumlah keseluruhan nilai hasil belajar adalah 800, nilai minimum 23, nilai maksimum 40, nilai rata-rata 32 dan varian 27,083.

Pengujian hipotesis hasil belajar menunjukkan bahwa terdapat pengaruh penggunaan media kartu penjumlahan dan pengurangan bilangan bulat pada hasil belajar matematika siswa kelas VII diperoleh bahwa $t_{\text {hitung }}>t_{\text {tabel }}(3,521>1,678)$, maka Ha diterima dan Ho ditolak.

Secara keseluruhan maka dapat disimpulkan bahwa terdapat pengaruh positif dan signifikan penggunaan media kartu penjumlahan dan pengurangan bilangan bulat pada hasil belajar matematika siswa kelas VII SMPN 3 Lage. Hal ini sesuai dengan pendapat Latuheru (Mustikasari, 2008) bahwa dengan menggunakan media pembelajaran dalam kegiatan belajar mengajar terjadi proses interaksi komunikasi edukasi yang baik antara guru dan siswa, sehingga hasil belajar pun menjadi lebih baik.

\section{KESIMPULAN}

Berdasarkan hasil penelitian dan pembahasan yang dilakukan, dapat disimpulkan bahwa Ha diterima yaitu terdapat pengaruh positif dan signifikan penggunaan media kartu penjumlahan dan pengurangan bilangan bulat pada hasil belajar matematika siswa kelas VII SMPN 3 Lage. Hal ini diperoleh setelah melakukan pengujian hipotesis dengan menggunakan rumus uji t-test polled varian $\left(\mathrm{dk}=\mathrm{n}_{1}+\mathrm{n}_{2}-2=24+25-2=47\right.$ ) berdasarkan taraf kepercayaan $95 \%$ uji pihak kanan diperoleh $t_{\text {hitung }}>t_{\text {tabel }}(3,521>1,678)$ dan untuk melihat pengaruh terdapat pengaruh positif ditunjukkan oleh $\left(\mathrm{O}_{2}-\mathrm{O}_{1}\right)-\left(\mathrm{O}_{4}-\right.$ $\mathrm{O}_{3}$ ) $>$, yaitu 5,127>0 maka dapat disimpulkan terdapat pengaruh positif.

\section{SARAN}

Berdasarkan hasil yang telah diperoleh dari penelitian ini, dalam meningkatkan hasil belajar khususnya pada mata pelajaran matematika, peneliti menyarankan sebagai berikut: 
- Siswa diharapkan untuk lebih meningkatkan minat dan perhatiannya terhadap mata pelajaran matematika dalam proses pembelajaran, baik pembelajaran menggunakan media kartu maupun menggunakan media pembelajaran lainnya sehingga hasil belajar matematika yang diperoleh akan semakin baik.

- Hasil penelitian ini dapat dijadikan acuan dasar untuk kepentingan dalam pembelajaran yang dapat memberikan konstribusi terhadap pemberian materi pada penjumlahan dan pengurangan bilangan bulat di SMPN 3 Lage.

- Bagi peneliti, agar dapat meneliti dan mengembangkan media pembelajaran sebagai bahan perbandingan untuk penelitian selanjutnya dalam meningkatkan kualitas pendidikan.

- Bagi pemerintah, diharapkan memberikan kebijakan untuk menyediakan media pembelajaran di Sekolah-sekolah untuk peningkatan hasil belajar yang lebih baik.

\section{DAFTAR PUSTAKA}

Aunurrahman. 2010. Belajar dan pembelajaran. Alfabeta, Bandung.

Dimyati \& Mudjiono. 2006. Proses belajar dan pembelajaran. Rineka cipta, Jakarta.

Gerlach, Vernon S. \& Donald P. Ely, 2011. Teaching and media. Prentice Hall, INC, New Jersy.

Hamalik, Oemar. 2006. Belajar mengajar. Bumi Aksara, Bandung.

Kemdikbud. 2013. Matematika kelas VII SMP/MTs buku siswa. Puskurbuk, Jakarta

Nasution, N. 2005. Penilaian hasil belajar. Pekerti, Jakarta.

Pujiati. 2006. Alat peraga sebagai media pembelajaran matematika. PPPG matematika, Yogyakarta.

Sadiman, Arief. 2006. Media pembelajaran, PT Raja Grajindo Perkada, Jakarta.

Sudjana, N. 2009. Penilaian hasil proses belajar mengajar. Remaja Rosda karya Bandung. , 2011. Penilaian hasil proses belajar mengajar. Remaja Rosda karya, Bandung.

Sugiyono. 2012. Metode penelitian kuantitatif, kualitatif dan $R$ dan D. CV Alfabeta, Bandung.

Suryabrata, 2002. Proses belajar mengajar. Rineka cipta, Jakarta.

Trianto. 2010. Model pembelajaran terpadu konsep, strategi dan implementasi dalam KTSP.

Bumi Aksara, Jakarta.

Widyantini dan Sigit. 2009, pemanfaatan Alat peraga dalam pembelajaran matematika di SMP. PPPPTK matematika, Yogyakarta.

Yus, Agusyana. 2011. Olah data Skripsi dan penelitian dengan SPSS 19. PT. Elek Media kompotindo Gramedia, Jakarta.

\section{Sumber Lain :}

Mustikasari, A. 2008. Mengenal Media Pembelajaran. (online), (http://eduartikel.com/mengenal-media-pembelajaran/), diakses 24 juni 2015 
Suharjana. 2009. Operasi penjumlahan \& pengurangan pada bilangan bulat dengan kartu. (online), (http://adwi-cute.blog.friendster.com/2010/05/operasi-penjumlahan-danpengurangan-pada-bilangan-bulat-dengan-kartu/), diakses 30 Juni 2015 